\title{
Owen Marriott*
}

\section{The Internet and Healthcare in Somalia: Knowledge is Power.}

\begin{abstract}
The introduction of the eight Millennium Development Goals (MDG's) by the UN has highlighted the need to improve healthcare conditions across the globe. These goals are particularly pertinent in Somalia, one of the least developed countries in the world. This paper intends to look at the way the burgeoning telecommunications network in Somalia can benefit healthcare professionals by providing access to the internet which in turn provides access to information that can improve healthcare. The paper will argue that although the development of healthcare is commonly associated with the modernization paradigm, the internet can offer a more participatory approach to benefit healthcare professionals in Somalia.
\end{abstract}

Key words: Development, healthcare, internet, Somalia, telecommunications.

* Owen Marriott is an MA Media and Journalism student at the University of Newcastle, United Kingdom. Authors Address: Hill View, Bodenham, Hereford, Herefordshire, UK, HR1 $3 H R$ 


\section{POLITICAL, SOCIAL AND ECONOMIC LANDSCAPE}

Ever since its independence from colonial rule Somalia has faced enormous problems politically, economically and socially. However, these problems were accentuated when President Siad Barre was overthrown in 1991 and the country subsequently plunged into a civil war. One of the main effects of this has been to split the country into three distinct regions: Somalia, Puntland and Somaliland in the North West. As a result, there is now no effective central government and this has hindered many developmental efforts in the country.

To compound the devastating effect that civil war has had in Somalia, the country has also been deeply affected economically by a ban on livestock exportation. Imposed in 2000 due to an outbreak of Rift Valley fever it has cost the country more than $\$ 120$ million annually in lost revenue (Ismail, 2006:6).

These problems have manifested themselves socially in that: 'the continued fighting and lack of any effective central administration has led to millions living in severe poverty and a virtual standstill in healthcare and education' (Uglow, 2006). According to the United Nations Development Project (2002), 43.2 percent now live in extreme poverty (under US\$1 a day) and 73.4 percent live in general poverty (under US\$2 a day).

However, nowhere more so can the impact of Somalia's instability be felt than in healthcare. The average life expectancy is just 46.2 years and a quarter of children die before they reach the age of five, mainly because: 'only 47 percent of pregnant women are attended to by professional healthcare personnel' (WHO, 2005:10).

The World Bank estimated that in 2001 as little as US\$29.30 was spent on healthcare per capita in sub-Saharan Africa compared to US $\$ 2,840.80$ in a high income country (Rhine, 2006:242). In Somalia this figure was as low as just US\$6 per capita in 2001 (WHO, 2006243). Furthermore, with an estimated population of 8.8 million people Somalia has only 310 trained doctors in the entire country (UN, 2007). Although HIV/AIDS infection rates are dramatically lower than in surrounding countries other healthcare problems such as malaria, tuberculosis and numerous other parasitic diseases are prevalent. For example, in 2002, over 11,000 people died from tuberculosis alone (WHO, 2005).

All these statistics amount to Somalia having some of the worst health indicators in the world. Furthermore, they highlight the need for a much improved healthcare system which is not only important from a humanitarian perspective but also from a developmental perspective. Healthcare, more than merely being a symptom of development can provide the very basis for development in that: 'ill health means irrecoverable losses in production...and lower productivity in general' (Rhine, 2006:243).

\section{MILLENNIUM DEVELOPMENT GOALS: A POSITIVE SOLUTION?}

In an attempt to help remedy some of the problems outlined, the UN has introduced the eight Millennium Development Goals (MDG's) to be achieved by 2015. Importantly, three of these were specifically aimed at healthcare; to reduce child mortality, to improve maternal health and to combat the spread of infectious diseases. 
Yet despite the positive intention of these goals they have nevertheless encountered a number of criticisms in relation to Africa, especially regarding their implementation and assessment of the current situation. For example, the MDG's are criticised for being a 'top down' process and universal rather than particular. This policy it has been argued will: 'exclude Local Authority and other stakeholders' involvement leading to an inherent danger that even if the targets were achieved then inequalities within a nation will still persist (Bond, 2006:3). As a result: 'many communities feel that they have been undermined by the agendas of donors and UN agencies instead of allowing communities to take their own approach to reaching the MDG's' (Wagner, 2003).

Furthermore, it has been argued that the MDG's are unrealistic for African nations because they are intended as a benchmark for global progress and not for individual countries, and this in turn may lead to the perpetuation of the myth of 'African failure'. Indeed, Jan Vandemoortele, a UN officer who co-chaired the inter agency group that compiled the MDG's said: 'assessing whether the progress is on track for meeting the 2015 targets can only be done at a global level, not on the basis of historical trends for any particular region or country' (Pollock, 2008). For example, reducing child mortality by two thirds poses a greater problem to Somalia which has an under 5 mortality rate of 225 per 1000 live births compared to a richer country that may only have a mortality rate of 25 . As a result, although Somalia may have made some progress to reducing child mortality, ultimately it will be negatively 'skewed' when measured against global indicators.

Irrespective of the criticisms levelled at the MDG's they still represent an important opportunity to promote better healthcare in Somalia. However, a UN report (2007:1) in 2007 states that: 'at the midway point for achieving the Millennium Development Goals, subSaharan Africa is not on track to achieve any'.

\section{THE TELECOMMUNICATIONS REVOLUTION}

The healthcare situation in Somalia, however, is not without hope and one avenue that has traditionally been used for development is the media. Furthermore, in an increasingly globalised world, the media takes on more significance, especially 'as in many other nations around the world, globalisation of the media, linked to the revolutionary advances in telecommunications, has left its imprint on Somalia' (Ismail, 2006:28).

In particular, Somalia has recently experienced a rapid surge in the growth of its telecommunications industry. This has no doubt been aided by the country's lack of an effective central government allowing private companies to grow unaffected by tax and state monopoly laws. As a result, three private phone companies - Telcom, Nationlink and Hormund - have come to the fore. Their success is evident in that it now takes 'just three days for a landline to be installed, compared with waiting lists of many years in neighbouring Kenya where there is a stable, democratic government' (Winter, 2004).

Furthermore, the installation of landlines has begun to create the necessary infrastructure for access to the internet. The three companies have now cooperated to set up the Global Internet Company which coexists alongside two other Internet service providers (ISP) - Abbitech and Africa Online. The Global Internet Company is, however, the only ISP provider owned by Somali nationals living in Somalia. It offers speeds of up to $15 \mathrm{mb} / \mathrm{second}$ within a $1.5 \mathrm{~km}$ radius of central Mogadishu and $11 \mathrm{mb} /$ second elsewhere, according to its products and services manager, Abulkadir Hassan Ahmed (Winter, 2004). This is particularly impressive considering Somalia's instability and the fact that only fifteen countries in the 
year 2000 had internet speeds of above $1 \mathrm{mb} / \mathrm{second}$ (Jensen, 2000:4). In addition to the increases in speed and availability, Somalia also boasts some of the cheapest internet rates in the whole of Africa with an hour costing as little as 50 cents (Winter, 2004).

This dramatic advance in the availability and speed of the internet offers the potential for healthcare professionals in Somalia to access a global wealth of knowledge and information. The importance of which is not to be underestimated: 'it was estimated that of approximately 50 million people who died each year in the 1980's, two thirds could have been saved through the application of existing but non available knowledge' (Geyoushi et al, 2003:501).

\section{DEVELOPING THE INTERNET AND HEALTHCARE IN SOMALIA}

Developing the internet as a source of information for healthcare professionals in Somalia highlights a wider debate over how communication can be used for development. Traditional strategies using the media for development in Africa have emanated from what can be called the dominant or modernization paradigm. This paradigm stresses individualism with a move away from the traditional to the modern and: 'health communication represents the strongest case for theories of development communication based on a theory of modernity' (Sparks, 2007:52).

One of the central tenants of this paradigm is the idea of knowledge transfer and the internet by offering access to a large database of new information on health issues reinforces this. Currently in Africa a lot of the medical information available is outdated and the 'concern in developing countries where at least two thirds of future physicians are being educated, is the lack of access to current scientific data to help in medical decision making' (Haddad \& MacLoud, 1999: 63). The internet can offer access to new advances in healthcare especially through online journal publications. An example of how this might directly benefit health professionals in Somalia is the HINARI project which began in 2003. As part of the project the World Health Organization and major publishers have made available over 3,000 medical journal titles to health institutions in developing countries for either a nominal fee or no cost at all (Rhine, 2006:245). In Somalia this would give doctors access to the latest advances on treating endemic conditions such as malaria and tuberculosis.

However, viewing the internet from the modernization paradigm of development highlights a number of issues as well. Firstly, there are questions raised about the power relationship that this transfer of knowledge engenders. By accessing Western medical journals online there is no input from Somali health professionals themselves and the majority of information is published by the global North with little emanating from the South itself. This may lead to dependency on the North for information thereby illustrating a need for an enhancement in the exchange of relevant information between the South (Rhine, 2006:248).

The modernization paradigm also assumes the notion of technological determinism. The idea being that by giving Somali healthcare professionals access to the internet the situation will automatically improve. Van Dijk and Hacker (2000) argue that this will not be the case: 'giving everybody a computer and a network connection will not remove inequality. Much deeper and clear cut differences in skills usage will come forward'. Therefore, there need to be efforts to train Somali health professionals to get the most out of the internet. Initiatives such as the Golanang project in South Africa, where public sector workers are supplied with computers and basic training, highlight the advantages of such schemes (Ryan, 
2002). However, one of the problems that Somalia faces is that these rely on government initiatives or central planning which is something Somalia cannot offer due to its political instability.

\section{THE INTERNET AND PARTICIPATION}

The internet though, is more democratic and participatory than the dominant paradigm of development would suggest. The dominant/modernization view on the internet as an aid to health professionals places the 'emphasis on teaching rather than an exchange of ideas between the centre and outlying areas' (Sparks, 2007:58). The internet offers the potential for Somali health professionals to participate in the exchange of information owing to the fact that it can 'receive as well as transmit' (Ojo , 2006: 97). Furthermore, many theorists have argued that 'participation in the use of ICT's in public health in Africa is essential if sustainable social change is to be achieved' (Ojo, 2006:94).

On a practical level the democratic nature of the internet enables Somali health professionals to be involved in the flow of health information around the global South. For example, Somalian healthcare workers can be part of a number of online forums such as the WHO/HIF-net which 'facilitates the transfer of existing knowledge and the generation of new ideas' (Ojo, 2006:97). As a testament to the success of this participatory system the number of members in Africa has increased dramatically from 62 in 2002 to 280 in 2004 (Porter, $2004 ; 118$ ).

Furthermore, the internet can facilitate interactive communication between hospitals and health professionals within Somalia itself. This takes on added importance because 65 percent of the population live in rural areas and most of the medical infrastructure is in the urban capital Mogadishu and Hargeisa in Somaliland (Ismail, 2006:4). Somalia can look to the way other countries in sub-Saharan Africa have adopted the internet to transfer information between institutions. For example, in Mozambique a link has been set up between three hospitals in different regions of the country which has allowed the transfer of medical records and the results of tests. In Senegal, a more advanced system has been used allowing video conferencing between hospitals in the capital Dakar and other regional hospitals (Ojo, 2006:96).

\section{IMPEDIMENT OF COST}

Despite the enormous potential of the internet to help healthcare professionals in Somalia, cost is the one underlying factor that mitigates its full integration. There needs to be substantial investment in the internet and infrastructure if it is to meet its full potential and although there has been rapid growth in the telecommunications sector, internet access is still very limited. One estimate suggests that there is as little as one computer for every 400,000 users (Rhine, 2006:244). Somalia, with its political problems and no central government, is in no position to fund this investment. The investment must therefore come from private companies and international bodies which may make Somalia dependent on their resources or technology. For example, even training initiatives like the Golaganang project rely on the purchase of equipment from Hewlett Packard (Ryan, 2002). 


\section{CONCLUSION:}

Irrespective of the problems of cost, however, the potential that the internet affords to healthcare professionals in Somalia should not be overlooked. Furthermore, the recent growth in telecommunications is beginning to make the internet a more viable option for improving healthcare. It enables healthcare professionals to be empowered through access to new information which in turn can help the country to meet some of the MDG's. Additionally, the internet offers the potential for more participatory communication within the global South and Somalia itself. This facilitates the dissemination of more relevant information as well as the generation of new ideas through mediums such as the internet forum.

While the internet may not be the complete answer to eradicating the healthcare problems of Somalia it does offer access to health information which 'is believed to be the single most cost effective and achievable strategy for sustainable development in healthcare' (Packenham - Walsh et al, 1997;90). If Somalia is to have any hope of achieving the MDG's by 2015 then the internet may yet prove to play a crucial role.

\section{REFERENCES}

Anon, 2008. Country Profile: Somalia. BBC News Online, Published 2008-03-06. http://news.bbc.co.uk/1/hi/world/africa/country_profiles/1072592.stm. Accessed: 2008-03-13.

Bond, P. 2005. Global governance campaigning and MDG's: from top-down to bottom-up anti-poverty work. http:/ www.choike.org/documentos/bond_mdgs_2005.pdf. Accessed: 2008-06-04.

Bourgault, L. 1995. Mass Media in Sub-Saharan Africa. Indiana: Indiana University Press.

Chapin Metz, H. 1992. Somalia: A Country Study. Washington: GPO for the Library of Congress. http://countrystudies.us/somalia/. Accessed: 2008-03-23.

Fahamu Report. 2002. Healthcare training and internet connectivity in Sub-Saharan Africa. http://www.fahamu.org/downloads/Nuffieldwebreport.pdf. Accessed: 2008-03-23.

Geyoushi, B. Matthews, Z and Stones, R. 2003. Pathways to evidence based productive healthcare in developing countries. British Journal of Obstetrics and Gynaecology. 110 (5): $500-507$.

Haddad, H. MacLoud S. 1999. Access to medical and health information for the developing world: an essential tool for change in medical education. Canadian Medical Association Journal, 160 (1): 63 - 64.

http://www.cmaj.ca/cgi/reprint/160/1/63? maxtoshow=\&HITS=10\&hits=10\&RESULTFORM $\underline{\mathrm{AT}}=\&$ fulltext $=$ haddad $+\&$ searchid $=1 \&$ FIRSTINDEX $=0$ \&volume $=160 \&$ issue $=1$ \&resourcetyp e=HWCIT. Accessed: 2008-03-13

Ismail, J.A. 2006. African media development initiative: Somalia. Research findings and conclusions. BBC World Service trust.org. 
http://downloads.bbc.co.uk/worldservice/trust/pdf/AMDI/somalia/amdi somalia full report.pdf. Accessed: 2008-03-13.

Jensen, M. 2000. African Internet Status, September 2000.

http://banners.noticiasdot.com/termometro/boletines/docs/consultoras/mikejensen/2000/apc jensen africa internet-2000 status.pdf. Accessed: 2008-03-17.

Ojo, T. 2006. Communication Networking: ICT's and health information in Africa. Information Development. 22 (94).

http://idv.sagepub.com/cgi/content/abstract/22/2/94. Accessed: 2008-03-13.

Packenham-Walsh, N. Priestley, C. and Smith, R. 1997. Meeting the information needs of health workers in developing countries. British Medical Journal, 314. 90.

Pollock, A. 2008. Africa: MDG's yardstick too generic, critics say.

http://www.allafrica.com/stories/200802070768.html. Accessed: 2008-06-04.

Porter, C. 2004. Networking for health: health professionals using email discussion forums for development. Information Development, 20 (2), 117 - 121.

Rhine, L. 2006. The impact of information technology on health information access in subSaharan Africa: the divide within the divide. Information Development. 22:242. http://idv.sagepub.com/cgi/content/abstract/22/4/242. Accessed: 2008-03-13.

Ryan, C. 2002. South Africa's Golaganang Project will connect government families to Internet. http://www.centerdigitalgov.com/international/story.php?docid=24791. Accessed: 2008-03-25.

Sonaike, S.A. 2004. The Internet and the Dilemma of Africa's Development. International Communication Gazette. 66(41). http://gaz.sagepub.com/cgi/content/abstract/66/1/41. Accessed: 2008-03-13.

Sparks, C. 2007. Globalization, Development and the Mass Media. London: Sage.

Uglow. 2006. Somalia Guide. http://uk.oneworld.net/guides/somalia/development. Accessed: 2008-03-29.

UNDP and World Bank. 2002. Somalia socioeconomic survey 2002. http://siteresources.worldbank.org/INTSOMALIA/Resources/swb complete report.p df. Accessed: 2008-03-13.

UN. 2007. Africa and the Millennium Development Goals 2007 Update. http://157.150.195.10/millenniumgoals/docs/MDGafrica07.pdf. Accessed: 2008-0323.

Van Dijk, J, and Hacker, K. 2000. The digital divide as a complex and Dynamic Phenomenon. Unpublished manuscript. International Communication Association Conference, Acapulco, Mexico, June. 
Wagner, D. 2003. 2000 Millennium development goals.

http://www.uiowa.edu/ifdebook/faq/MDG.shtml. Accessed: 2008-06-04.

WHO, 2005. Somalia Biennial Report 2004 - 2005.

http://www.emro.who.int/somalia/publications-reports.htm. Accessed: 2008-03-21.

WHO, 2006. Somalia Annual Report 2006.

http://www.emro.who.int/somalia/publications-reports.htm. Accessed: 2008-03-20.

Winter, J. 2004. Telecoms thriving in lawless Somalia. BBC News Online.

http://news.bbc.co.uk/go/pr/fr/-/2/hi/africa/4020259.stm. Accessed: 2008-03-13. 